\title{
芝生の校庭による校内の暑熱環境の緩和に関する CFD 解析による検討 CFD ANALYSIS ON MITIGATION EFFECTS TO THE THERMAL ENVIRONMENT OF A SCHOOL SITE IN SUMMER BY LAWN PLANTING TO THE PLAYGROUND
}

\author{
梅田和 彦*, 深尾 仁**, 大黒雅之** \\ Kazuhiko UMEDA, Hitoshi FUKAO and Masayuki OGURO
}

\begin{abstract}
Lawn planting in school playground scattered in urban areas is expected to mitigate the heat-island phenomenon. If lawn planting in school playground is realized, a new green area of about several thousands square meters will be created in the central block of city, where the wide expansion of planting areas has been considered to be difficult.

This paper compares the summer thermal environment in a school when its playground is covered with lawn and when it is not covered with, namely of soil ground. The comparison is conducted by using computational fluid dynamics (CFD) analysis based on the measurement results on a primary school located in one of the wards in Tokyo. Our major finding through this study is introduced as below:

1) In a region of school playground where airflow stagnates, the thermal index of standard new effective temperature (SET*) in the playground covered with lawn is tended to be lower by approximately $1{ }^{\circ} \mathrm{C}$ compared to that when it is with soil ground.

2) Under the condition when the air above the school playground enters into the classroom where the airflow velocity of approximately $0.5 \mathrm{~m} / \mathrm{s}$ is observed, the temperature of the room with the playground covered with lawn is tended to be lower by approximately $1{ }^{\circ} \mathrm{C}$ compared to that when it is with soil ground.
\end{abstract}

Keywords : school playground, lawn, classroom, thermal environment, field measurement, numerical simulation 校庭, 芝生, 教室, 温熱環境, 実測調查, 数值シミュレーション

\section{1. 序論}

昼間人口が増加する都市中心部では, 道路の整備や建物の建設に 伴う人工被覆面の増大と自動車や空調機器の増加に伴う人工排熱の 増大等によって, 夏季において郊外より気温が上昇するヒートアイ ランド現象が問題になっている。この問題の緩和策として,植物の 蒸散作用における気化熱で地上付近の気温の上昇を抑制する方法が あり，筆者ら ${ }^{1}$ は熱緩和効果の基礎的な検討として，夏季におけ る樹木の蒸散量や芝生の蒸発散量の実測調查を実施している。

代表的な植栽には, 街路樹, 公園の樹木や芝生, 屋上緑化等があ るが, 過密化した都市空間では植栽面積の大幅な増大は困難であ る。このような状況で, 都市に点在する学校の校庭を芝生化できれ ば, 都市中心部で数千 $\mathrm{m}^{2}$ 程度の䌅まった緑地面積の確保が可能に なる。また, 校庭の芝生化には, 情操教育, 砂塵の飛散防止, 怪我

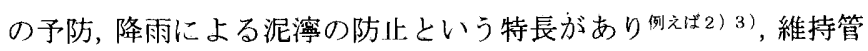
理体制の整備が伴えば実施校が増加すると期待されている。

校庭の芝生化に関する既往の調査については, 芝生育成の観点か ら主に農学分野で報告例例えば4) があるが, 暑熱環境の緩和効果に ついては，定性的に効果があると予想されてはいるものの，定量 的な効果を報告する文献は少なく例立ば5)，十分な調查がなされてい るとは言い難い。また, 生徒や職員の生活環境改善の観点から, 芝 生の校庭の空気が空を開けた校舎内一流入する場合の室内温熱環 境についても十分に調査されていない, 以上のとおり，校庭の芝生 化による校内への熱的な影響については不明な点が残されている。

参考文献として, 都市の大規模な緑地を対象にした暑熱環境の緩 和に関寸る既往の調査には，例えば，神田ら ${ }^{6)}$ は明治神宮の森内
部の気温低下量を, 尹ら ${ }^{7)}$ は緑地規模と緑地内外の気温低下との 関連を, 森山ら ${ }^{8)}$ は街路と樹林の熱環境の比較結果を報告してお り，1haを超える大規模な植栽による暑熱環境の緩和効果の害態を 把握するうえで意義深い。また, 植栽による建物周用の微気象緩和 に関する既往の調査には, 例えば，山田ら ${ }^{9)}$ は住宅団地の気温分 布の経時変化を, 佐藤ら ${ }^{10}$ ) は住宅団地の植栽による住棟間の気象 変化を報告しており,植栽の微気象調節の実態を把握するうえで参 考になる。しかしながら，以上の文献をはじめ既往の実態調査は， 植栽が既にある状況での気候緩和を対象とするものが多く, 同じ場 所での植栽前後の熱環境の変化に言及寸る実態調査は少ない。植栽 は地表被覆面の水分放出を改善して暑熱環境を緩和する対策なの で，植栽前後の気象変化を評価の観点にした議論も必要である。

校庭の芝生化による暑熱環境の緩和効果の評価には, 同じ校庭で 十の場合と芝生の場合の熱環境を現地測定で比較する方法が考えら れるが，筆者らが調査する学校は，調査年の6月に校庭を土から芝 生にする工事を行うため, 夏季に打ける土の校庭の現地測定が不可 能である。本研究では, 十の校庭や芝生の校庭の放射特性や蒸発効 率等の物理量の測定值をCFD (Computational Fluid Dynamics: 計 算流体力学)による数值シミュレーション(以下, CFD解析) の与条 件にして, 十の校庭や芝生の校庭による校内の熱環境を比較する。

本論文では, 既報11) を修正し, SET*(Standard New Effective Temperature: 標準新有効温度) ${ }^{12)}$ による評価と, 校庭の空気が空 を開けた校舎内へ流入した場合の室内温熱環境について検討した 結果を加筆して, 校庭の芝生化による校内の暑熱環境の緩和効果 を報告する

\begin{tabular}{|c|c|}
\hline $\begin{array}{l}\text { * 大成建設(侏)技術センター } \\
\text { * 大成建設設侏技術センター } \\
\text { 博士 (工学) }\end{array}$ & $\begin{array}{l}\text { Taisei Technology Center, Taisei Corporation, M. Eng. } \\
\text { Taisei Technology Center, Taisei Corporation, Dr. Eng. }\end{array}$ \\
\hline
\end{tabular}




\section{2. 調查の概要}

\section{1 調查の方針}

CFD解析の与条件に, (1)現地調查で士の校庭と芝生の校庭の放射 特性 (日射反射率, 長波長放射反射率)や, 校舎屋上の風向風速と温 湿度や, 校庭の地中温度を, (2)屋外実験で校庭の十と芝生の蒸発効 率を各々測定した值を用いて，校舎や近隣建物の形状や配置を再 現した計算モデル（樹木は除く）で計算する。放射特性の測定では, 校庭の芝張り前の 5 月注1) に土の校庭を, 芝張り後の 8 月に芝生の 校庭を各々測定する。調査の方針を図 1 に、測定機器を表 1 に各々 示す。なお，解析結果との比較のため，校庭の風向や温湿度と，犬 走りや教室の空気温度についても 8 月に測定する。

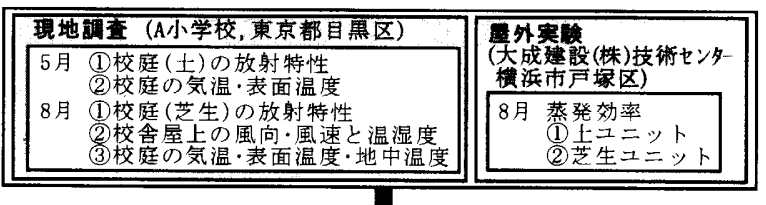

CFDによる稙シミュレーション

図 1 調查の方針

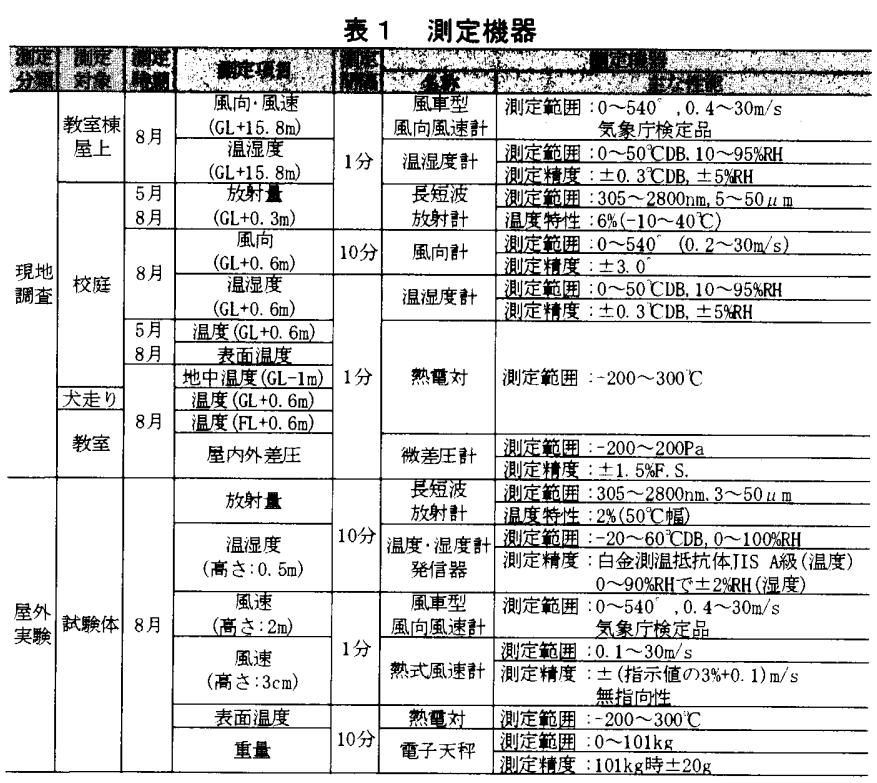

\section{2 現地調査の概要}

\section{(1) 現地の概要}

建物の配置図を図 2 に示す。現地は, 第一種低層住居専用地域に ある $\mathrm{A}$ 小学校 (東京都目黒区)で, 敷地周囲の建物は南東側に地上 4階建ての共同住宅がある他は, 大半が地上2階建ての住宅である。 敷地の北東側と北西側には地上3階建ての教室棟が, 南西側には地 上3階建ての体育館がある。校庭は図 2 の範囲で当初は土であるが， 平成 16 年6月に芝張りを行い, 図 2 の芝張り範囲が芝生(面積は約 $1500 \mathrm{~m}^{2}$ ) になっている。なお，芝生の育成のため夏季(調查期間を含 む) は毎朝 8 時頃芝張り範囲に散水 (約 $\left.5 \mathrm{~L} / \mathrm{m}^{2}\right)$ している。

(2) 調査の概要

放射特性の測定は降雨が無い晴天日に行い，校庭が士の場合は 平成 16 年 5 月 24 日に, 校庭が芝生の場合は平成 16 年 8 月 12 日以 降3 日間実施する。測定位置は, 図 2 に示す校庭中央付近である。な お，芝生への測定機器類の設置時間が長いと芝生の育成に支障を きたす恐れがあるので, 芝張り後は校庭の風向と温湿度の分布や, 芝生表面の温度や放射量の測定は朝から夕方までに限定する。

校庭の長波長放射反射率については, 現地調査で測定した校庭の 長波長放射量と表面温度を式(1)に代入して算出する

$$
\rho_{L}=1-\varepsilon_{L}=1-\frac{L \uparrow}{\sigma T_{S}^{4}}
$$

ここで， $\rho_{L}$ : 校庭の長波長放射反射率

$\varepsilon_{L} \quad:$ 校庭の長波長放射放射率

$L \uparrow:$ 校庭の長波長放射量

$\sigma \quad$ : Stephan-Boltzmann $の$ 定数

$T_{s} \quad:$ 校庭の表面温度
$[-]$
$[-]$
$\left[\mathrm{W} / \mathrm{m}^{2}\right]$
$\left.\mathrm{W} /\left(\mathrm{m}^{2} \cdot \mathrm{K}^{4}\right)\right]$

[K]
$\left[\mathrm{W} /\left(\mathrm{m}^{2} \cdot \mathrm{K}^{4}\right)\right]$

上空の風向風速と温湿度は図 2 に示す教室棟の屋上 $(\mathrm{GL}+15.8 \mathrm{~m})$ で, 校庭 $(\mathrm{GL}-1 \mathrm{~m})$ の地中温度は図 2 に示す場所で, 校庭や犬走り $(\mathrm{X}-$ $X^{\prime}$ 断面の校庭側) での気温は $\mathrm{GL}+0.6 \mathrm{~m}$ の高さで, 教室 $(X-X$ ' 断面 の 1 階から 3 階)の室温は FL $+0.6 \mathrm{~m}$ の高さで校庭の表面温度と共に 平成 16 年 8 月 8 日から 1 週間測定する。なお，校舎内の通風の有無 の判定のため, 空面での風圧による屋内外差圧を併せて測定する。

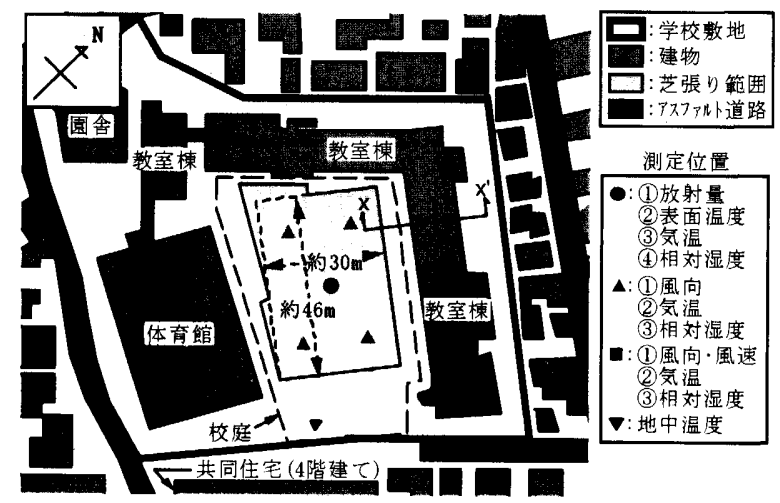

図 2 校舎と校庭の配置

\section{3 屋外実験の概要}

蒸発効率の測定は, 試験体一充分に散水した翌日以降, 降雨が無 く晴天が続いた平成 16 年 8 月 8 日から 1 週間, 大成建設侏技術七 ンター(横浜市戸塚区) 敷地内にある建物屋上で周囲に日射遮蔽物 が少ない場所で実施する。試験体の材料構成注2)を図 3 に示す。試験 体は平面寸法が $45 \mathrm{~cm}$ 角で上面以外は $5 \mathrm{~cm}$ 断熱材で用まれている。 なお, 芝生ユニットへの散水は, 現地の校庭での散水時刻にあわせ て毎朝散水(約 $\left.5 \mathrm{~L} / \mathrm{m}^{2}\right)$ する。

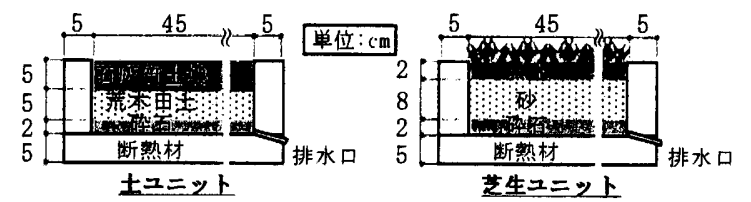

図 3 試験体の材料構成

蒸発効率は, 測定で求めた試験体表面の水分放出量, 湿気伝達率 飽和水蒸気圧, 外気の水蒸気分圧を式 $(2)^{13}$ ) に代入し算出する。

$$
\begin{aligned}
& \beta=\frac{E}{A \alpha_{W}\left(f_{S}-f_{a}\right)} \\
& \text { ここで, } \beta \text { : 蒸発効率 } \\
& E: \text { 水分放出量 } \\
& f_{a}: \text { 外気の水蒸気分圧 }
\end{aligned}
$$$$
A \text { : : 面積 } \quad\left[\mathrm{m}^{2}\right]
$$$$
\alpha_{W} \text { : 湿気伝達率 }\left(=7 \times 10^{-6} \alpha_{c}\right) \quad\left[\mathrm{kg} /\left(\mathrm{m}^{2} \cdot \mathrm{s} \cdot \mathrm{kPa}\right)\right]
$$$$
\left.\alpha_{c} \text { : 対流熱伝達率 [W/ }\left(\mathrm{m}^{2} \cdot \mathrm{K}\right)\right]
$$$$
f_{S}: \text { 試験体上面の飽和水蒸気压 }[\mathrm{kPa}]
$$

水分放出量は, 電子天秤で重量减少量を自動測定して求める。な お, 風圧による重量変化の抑制のため試験体の周囲に風避け用のス ロープを設ける。表面温度は任意の 5 箇所の平均值で, 芝生ユニッ トでは葉群層最上部付近の温度である。対流熱伝達率は, 試験体表 面 $3 \mathrm{~cm}$ 高さの風速をJürgesの強制対流熱伝達率の式に用いて算出寸 る。飽和水蒸気圧は, Sonntagの式 (JIS Z 8806-2001) で算出する。 


\section{3. 測定の結果}

\section{1 現地調查の結果}

校庭 (芝生) での放射量，気温，表面温度，地中温度を図 4 に示 す。測定期間の天候は 8 月 10 日と 8 月 11 日に一次的に量りになる 他はよく晴れて，全天日射量が 8 月 12 日からの 3 日間で気象庁の 観測值（東京都港区）とほぼ同様に推移する。測定期間の校庭中央 (GL+0.6m) での最高気温は連日 $35^{\circ} \mathrm{C}$ を越え，表面温度の最高は 8 月 13 日に $40^{\circ} \mathrm{C}$ を越える他は良く晴れると $40^{\circ} \mathrm{C}$ 近くまで上昇し, 地中 温度 $(\mathrm{GL}-1 \mathrm{~m})$ は約 $28^{\circ} \mathrm{C}$ でほぼ一定である。なお, 5 月 24 日に測定 し た校庭 (土)中央での気温と表面温度の 11 時から 16 時までの平均は 各々 $24.2^{\circ} \mathrm{C}$ と $29.7^{\circ} \mathrm{C}$ (全天日射積算量 $20.9 \mathrm{MJ} /\left(\mathrm{m}^{2}\right.$ ・日)) である

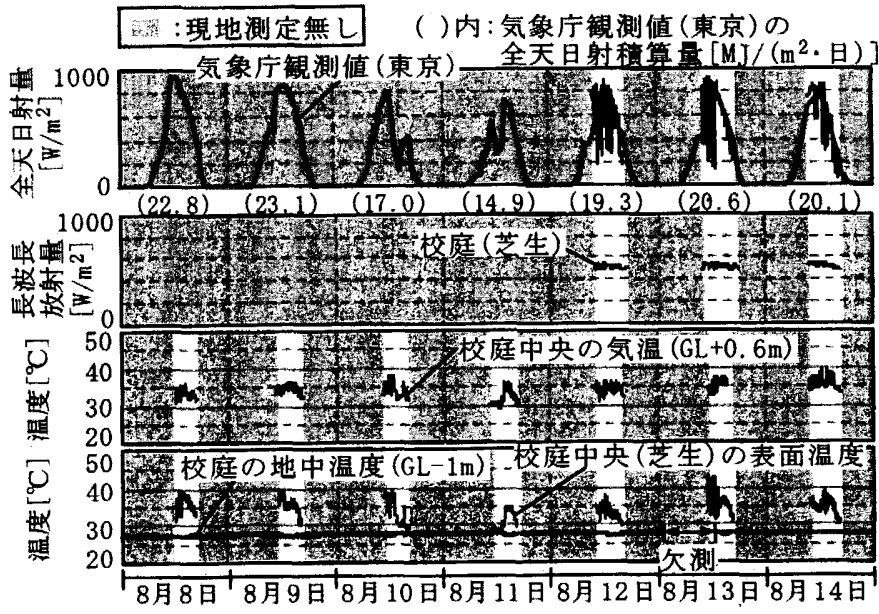

図 4 校庭 (芝生)での放射量・気温・表面温度・地中温度

校庭の日射反射率を図 5 に示す。全天日射量が $500 \mathrm{~W} / \mathrm{m}^{2}$ 以上での 日射反射率の平均值は土の校庭は約 $17 \%$ で, 芝生の校庭は約 $24 \%$ で あり，芝生の校庭は土の校庭よりも約 7\%多く日射を反射する

教室棟屋上の風向頻度を図 6 に，風速と温湿度を図 7 に各々示 す。測定期間の 9 時から 17 時における主風向は南東である。風速は 昼間が夜間より大きく最大風速は連日 $3 \mathrm{~m} / \mathrm{s}$ 超える。気温は久測を 除き毎日 $35^{\circ} \mathrm{C}$ 前後まで上昇し，相対湿度は昼間で $40 \%$ から $60 \%$ 程 度で推移する。現地調査の結果を総括すると表 2 のとおりである。

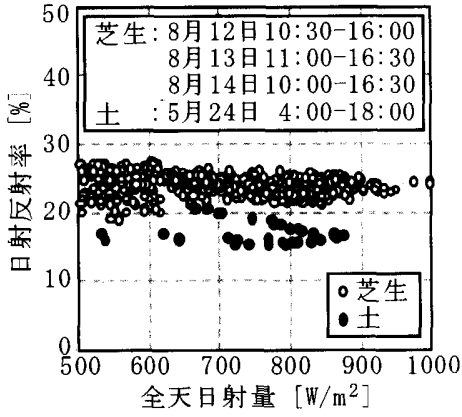

図 5 校庭の日射反射率

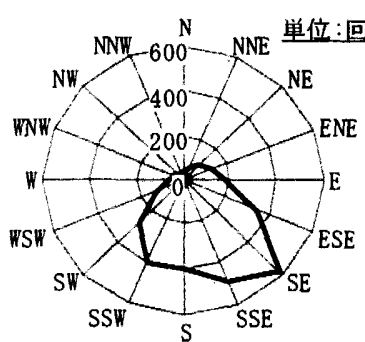

住)平成 16 年の8月8日から8月14日 に㧍け万時加ら17時の時間带 での風向頻度

図 6 教室棟屋上の風向頻度

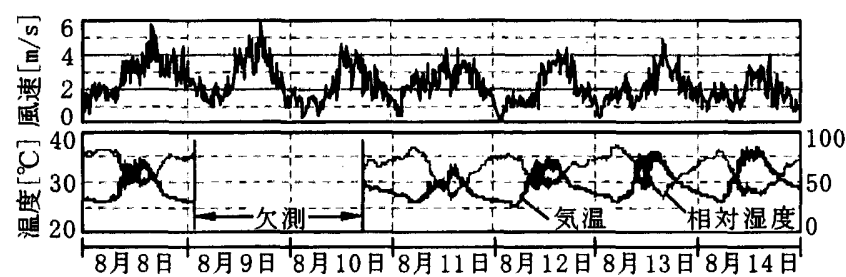

図 7 教室棟屋上の風速・温鼬度

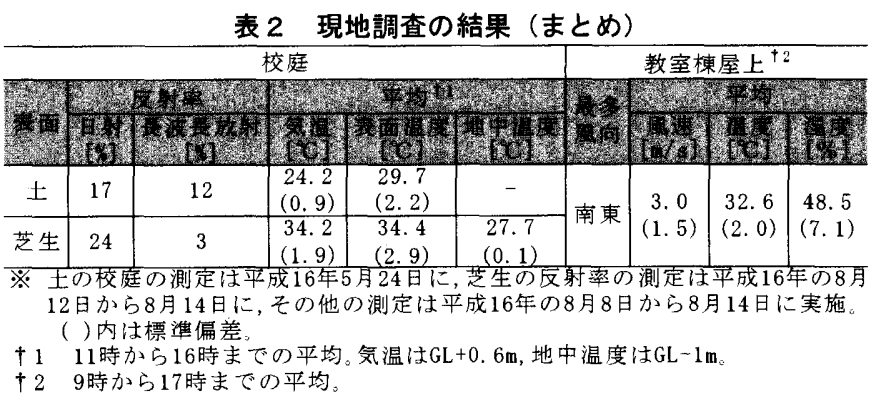

\section{2 屋外実験の結果}

充分に散水した翌日から降雨が無く晴天日が連続した1週間の気 象状況と, 試験体の表面温度，水分放出量，蒸発効率を図 8 に示 す。天候は現地調査(東京都目黒区) と同様の傾向で, 全天日射量は 8 月 11 日を除き $20 \mathrm{MJ} /\left(\mathrm{m}^{2} \cdot\right.$ 日) 前後で良く晴れている。最高気温は連 日 $30^{\circ} \mathrm{C}$ 以上で，相対湿度は昼間で $40 \%$ から $60 \%$ 程度で推移してい る。風速は昼間が夜間より大きく，試験体上部 $2 \mathrm{~m}$ の高さでは最大 $4 \mathrm{~m} / \mathrm{s}$ 程度で, $3 \mathrm{~cm}$ の高さでは最大 $2 \mathrm{~m} / \mathrm{s}$ 程度である。表面温度の日最 大值は，一次的に曇った 8 月 11 日を除いて芝生ニニットで約 $38^{\circ} \mathrm{C}$ とほぼ同じ值であるのに対して，土ユニットは水分放出量の減少 に伴って晴天日 1 日目 $\left(8\right.$ 月 8 日) 以降 3 日間で約 $35^{\circ} \mathrm{C}$ から約 $55^{\circ} \mathrm{C}$ で約 $20^{\circ} \mathrm{C}$ 上昇し，水分放出量が減少して安定する晴天日 5 日目 $(8$ 月 12 日) 以降 3 日間では $55^{\circ} \mathrm{C}$ 前後で安定する。蒸発効率は式(2)に 示すと打り水分放出量の関数である。図8では蒸発量が多くなる昼 間 (10 時から 15 時)における蒸発効率を示す。毎朝散水するため, 晴天日が連続しても水分放出量が $5 \mathrm{~mm} /$ 日以上を確保して減少しな い芝生ユニットでは, 蒸発効率の日最大值は 1 前後注3) と蒸発が活 発である。一方, 散水しない土ユニットでは晴天日 1 日目から晴天 日 7 日目にかけて水分放出墨が約 $7 \mathrm{~mm} /$ 日から約 $1 \mathrm{~mm} /$ 日と約 $6 \mathrm{~mm} /$ 日減少するに伴い, 蒸発効率の日最大值は1強注4) からほぼゼ口ま で減少し表面が乾燥する。なお，上ユニットの水分放出が安定した 8 月 12 日以降 3 日間で欠測がない 10 時から 15 時 (図 8 の蒸発効率 のグラフで色塗りの部分)に扔ける蒸発効率の平均值は，十ユニッ トが 0.07 で芝生ユニットが 0.74 である

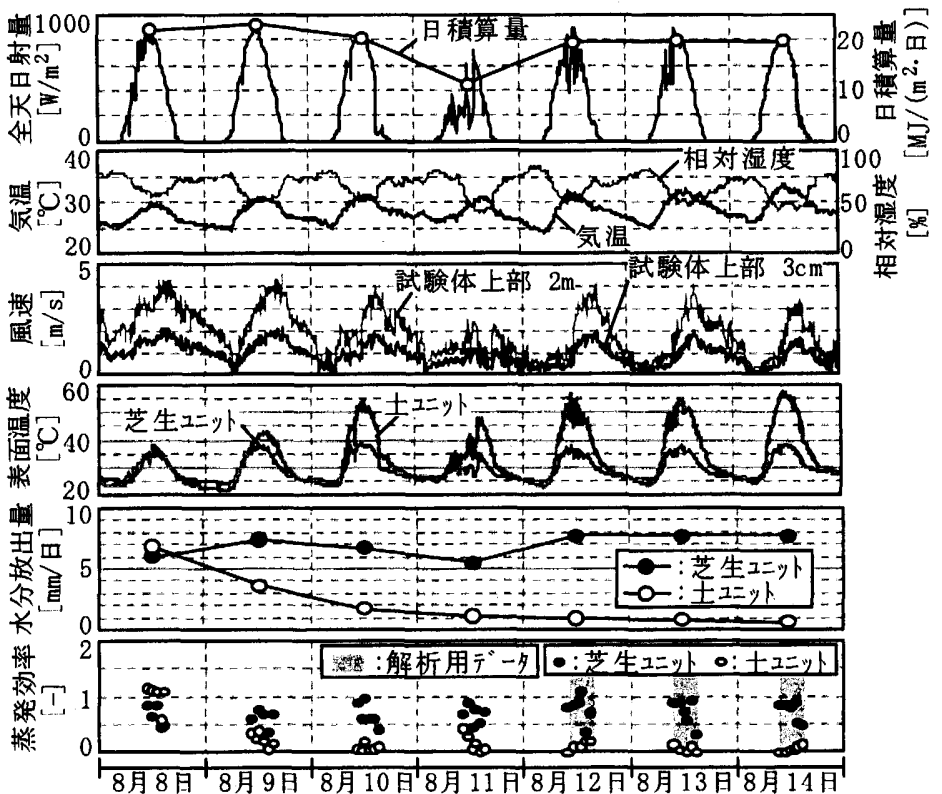

図 8 屋外実験での気象状況と試験体の表面温度・水分放出量・蒸発効率 
4. CFD 解析による検討

\section{1 計算の概要}

計算では対流・放射・湿気輸送連成によるCFD解析 ${ }^{16)}$ を定常状態 を想定して行う。乱流モデルは標準k- $\varepsilon$ モデルである。計算方法を 表 3 に示す。計算領域は平面 $400 \mathrm{~m}$ 角で高さ $100 \mathrm{~m}$ の空間で, 非構造 格子で分割し, 敷地境界から南北 $185 \mathrm{~m}$ 東西 $140 \mathrm{~m}$ の範囲にある建物 の形状を再現する。

表 4 計算ケース

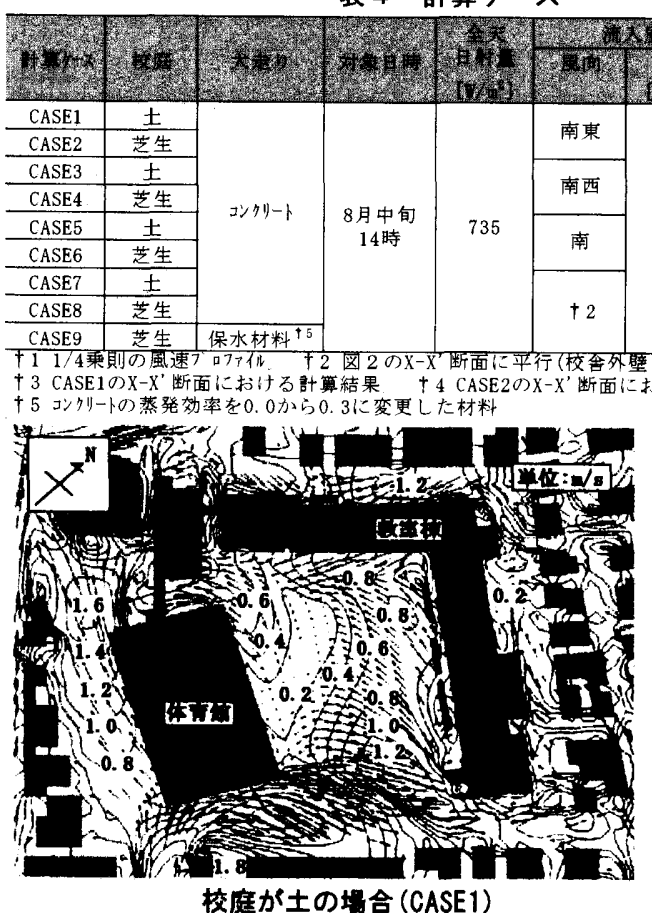

a) 風违

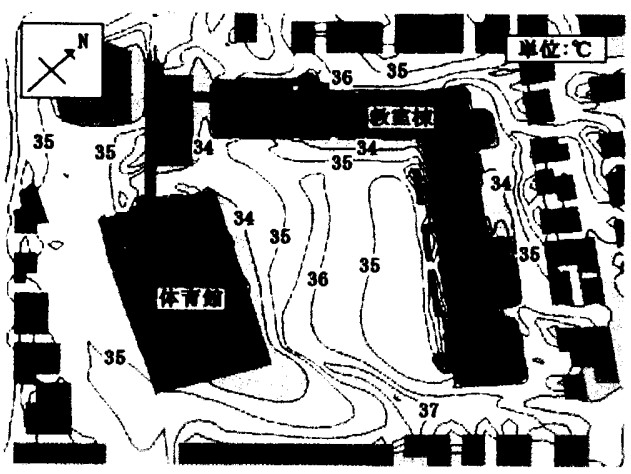

校庭が土の場合 (CASE1)

b) 気温

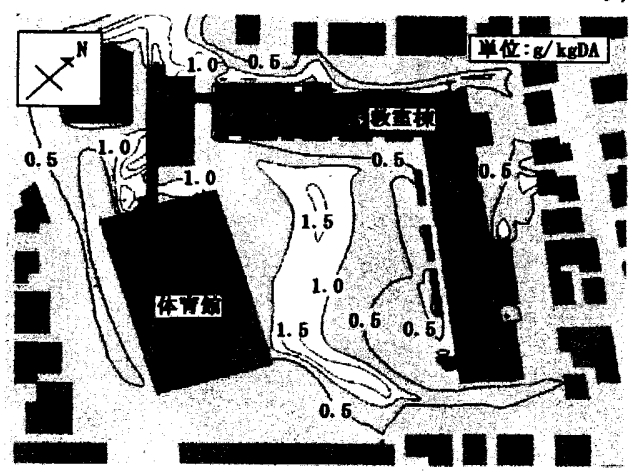

校庭が土の場合 (CASE1)

c) 絶対湿度の増加至

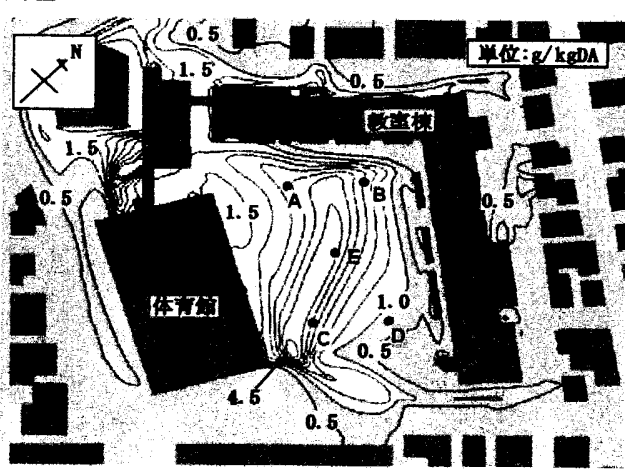

校庭が芝生の場合 (CASE2)

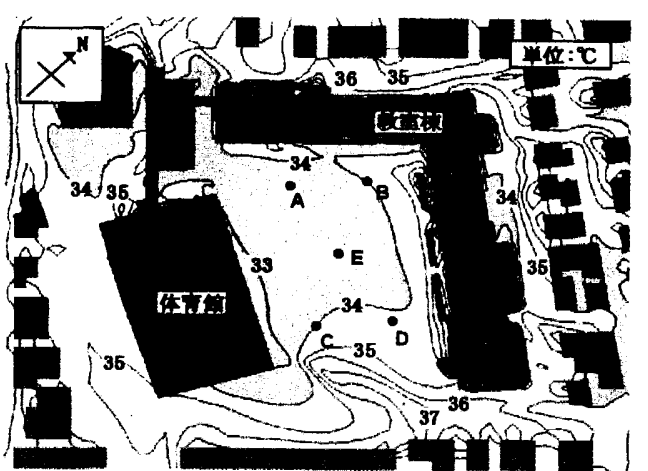

校庭が芝生の場合 (CASE2)
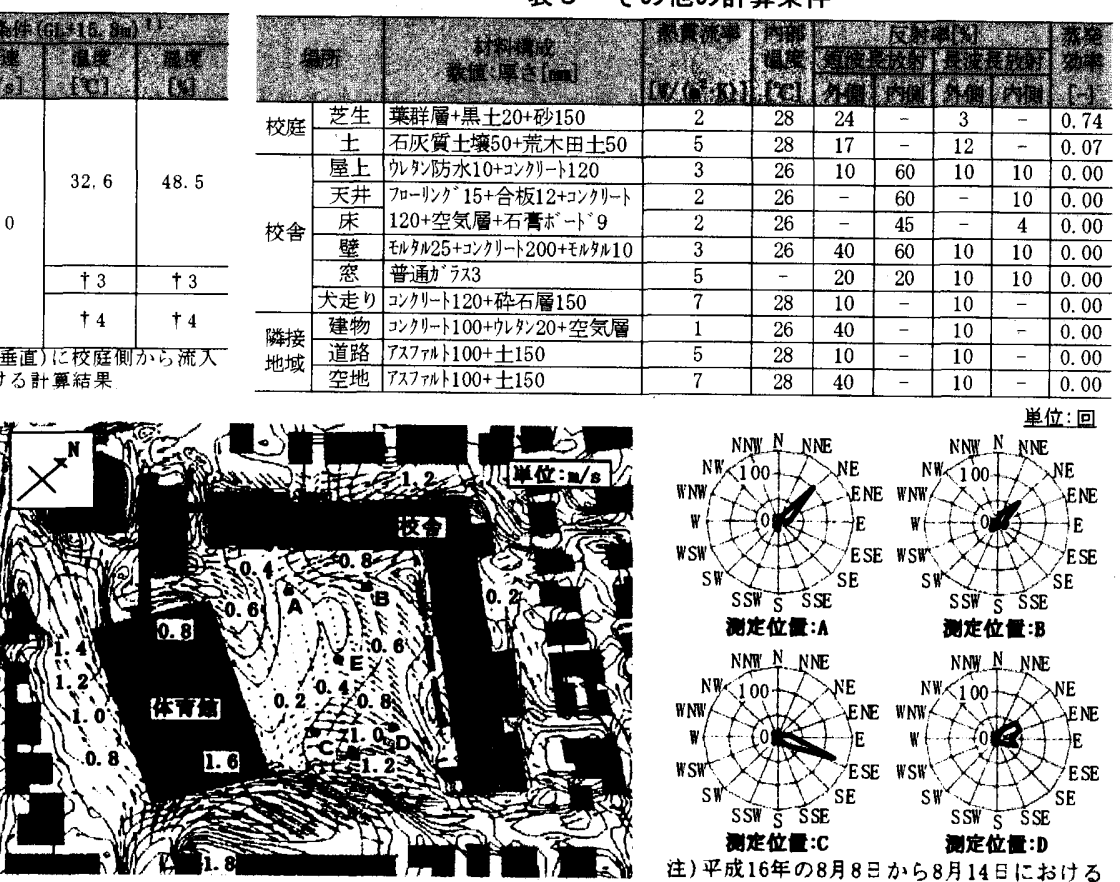

校庭が芝生の場合 (CASE2)

枌庭が芝生の均合 (CASE2)

図 9 校庭 $(\mathrm{GL}+0.6 \mathrm{~m})$ の環境物理量の比較 南東風 $(\mathrm{GL}+15.8 \mathrm{~m})$ の場合
表 5 その他の計算条件

表 3 計算方法

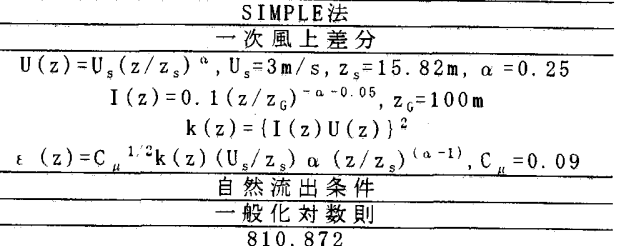

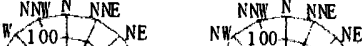

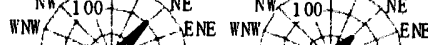
N-DOC. WSW 7 S ESE WSW $\times 77 \times$ ESE SSW S SSE SE SUT SSI S SSE

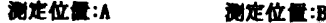
NNW N.NNE NNY N NNE

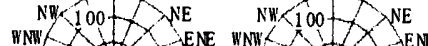
- fol SUT $>1$ X $X$ ESE WSW SSW S SSE SE SH SSI' S SSE SE

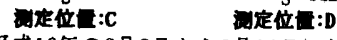
注)平成16年の8月8 8か.58月14 巨における 11時から16時の時閶带での風向頻度。

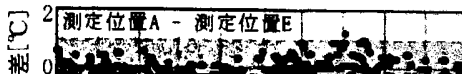

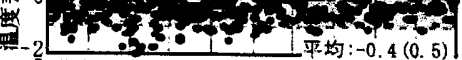

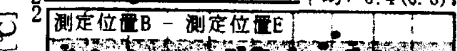

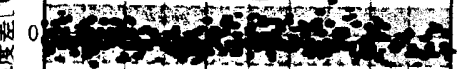

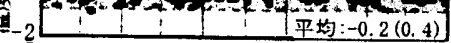

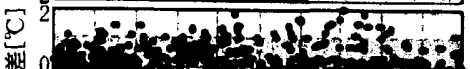

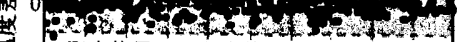

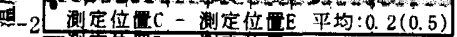
$\Xi^{2}-1 d_{1}$

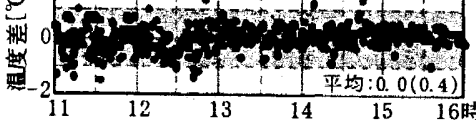

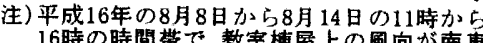

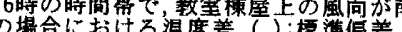

$2401 \div 1$

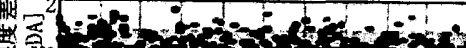

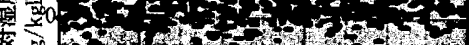

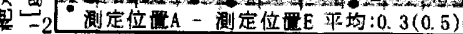
H

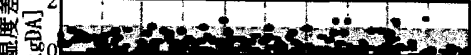

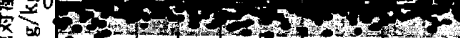

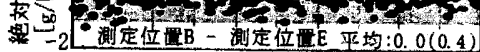

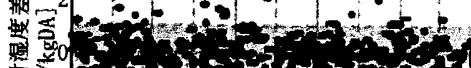
柴

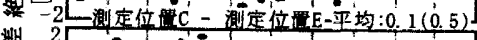

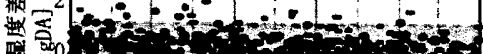

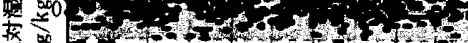

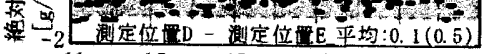

注)平成16年の8月8日から8月 14 日 21511 時から 16時の時間带で，数窑棟屋上の風向加南東

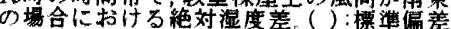


計算ケースを表 4 に示す。計算対象時刻は気温が最も高くなる 14 時で8月中旬の太陽位置を設定し, 全天日射量には晴天で日射の変 動が小さい平成 16 年 8 月 14 日の正午前後 10 分の平均值(現地調査 の測定結果)を用いる。流入風条件には, GL+15,8mの高さの風速に 表 2 に示寸風速の傎を用いた $1 / 4$ 乗則の風速プロファイルで, また ，温湿度についても表 2 に示す値を与える。

校庭や校舎と隣接地域の建物や地表面に関する計算条件を表 5 に示す。校庭や校舎の材料構成では現地の状況を再現する。芝生の 熱貫流率の計算では芝生葉群層の熱抵抗 ${ }^{18)}$ を考虑する。内部温度 は現地調査に基づく類推值である。校庭の反射率には表 2 に示す測 定値を用いる。また，校庭の蒸発効率には，図 8 に示す 8 月 12 日以 降 3 日間の 10 時から 15 時の平均值を用いる。なお，水分放出は校 庭のみ，教室棟と体育館の空は全開の状態を設定する。

\section{2 CFD 解析の結果}

\section{（1）校庭の風速・気温・絶対湿度増加量の分布}

児童の人体中心の高さに近い $\mathrm{GL}+0.6 \mathrm{~m}$ の平面において，校庭の 風速, 気温, 絶対湿度の増加量の各分 布を，現地調査の昼間の測定結果と 併せて図 9 に示す。流入風条件で設定 する風向は，現地調查の測定結果で ある主風向の南東で設定高さは GL+15.8m である

校庭の風速分布 (図9のa)について は，校庭が十の場合と芝生の場合で の差違は小さい。学校敷地の南東側に 隣接する地上 4 階建ての共同住宅の 北東側と南西側から校庭一風が流入 し，教室棟の校庭側外壁に沿って教 室棟の南西側と体育館の北西側から 隣接地域へ流出する風の大きな流れ ができるため，校庭の体育館側に風 速が $0.5 \mathrm{~m} / \mathrm{s}$ 以下の気流が停滞する領 域ができる。また，現地調查の昼間の 風向頻度 $(G L+0.6 \mathrm{~m}$ ) は校庭西側 (測定 位置A）と校庭南側 (測定位置C) でCFD 解析結果と同じ傾向がある

校庭の気温分布（図9のb)につい ては, 校庭が土の場合, 校庭の体育館 側に温度が高い $36^{\circ} \mathrm{C}$ の帯状の空気が あり，風速が $0.5 \mathrm{~m} / \mathrm{s}$ 以下の領域とほ ぼ一致することから，校庭の地表面 付近の空気が土で暖められやすく なっていると考えられる。一方，校庭 が芝生の場合, 風速が $0.5 \mathrm{~m} / \mathrm{s}$ 以下の 領域の気温が校庭が十の場合に比べ2 ${ }^{\circ} \mathrm{C}$ か $3{ }^{\circ} \mathrm{C}$ ほと低下して, $34^{\circ} \mathrm{C}$ 以下の 領域 (色塗り部分) が校庭中央付近ま で広がる。これは, 芝生の蒸発散によ る熱緩和効果が十の蒸発による場合 より大きいことが原因である。また，
現地調査の昼間 (11時から16時) で教室棟屋上の風向が南東の場合 における校庭 $(\mathrm{GL}+0.6 \mathrm{~m})$ の気温分布には, 校庭中央(測定位置E)に 対して校庭南東側 (測定位置C) が平均で約 $0.2^{\circ} \mathrm{C}$ 高く, 校庭西側 (測 定位置A) が平均で約 $0.4^{\circ} \mathrm{C}$ 低く, CFD解析の結果が示す校庭の風下 側で気温が低下する傾向と同様な傾向がある。

校庭の絶対湿度の増加量の分布 (図 9 の c) については, 校庭が 芝生の場合, 風速が $0.5 \mathrm{~m} / \mathrm{s}$ 以下の領域で絶対湿度の増加量が多く なり，校庭が土の場合に比べて絶対湿度の増加量が $2 \mathrm{~g} / \mathrm{kgDA}$ から $3 \mathrm{~g} / \mathrm{kgDA}$ ほど多くなる。れは, 芝生の蒸発効率が十の場合より高 いことが原因である。また，現地調査の昼間 (11 時から 16 時) で教 室棟屋上の風向が南東の場合における校庭 $(\mathrm{GL}+0.6 \mathrm{~m})$ の絶対湿度の 分布は, 校庭中央 (測定位置E) に対して校庭西側 (測定位置A) が平 均で約 $0.3 \mathrm{~g} / \mathrm{kgDA}$ 高く, 校庭の地表面付近での湿気の移流現象を微 量ではあるが確認できる

（2）風向による校庭の SET* の分布

流入風条件で設定する $\mathrm{GL}+15.8 \mathrm{~m}$ の高さにおける風向を南東, 南

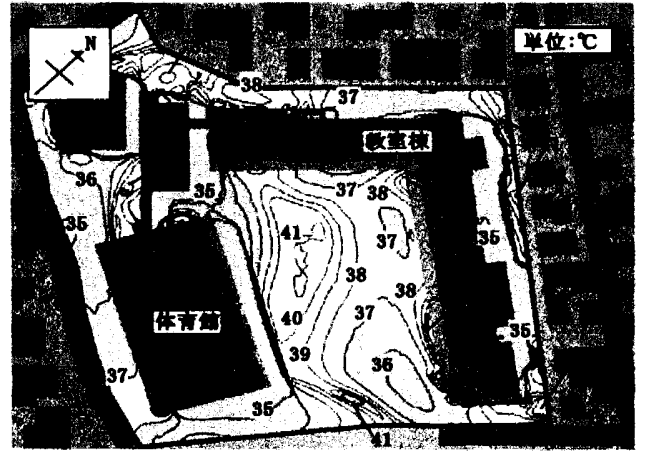

校庭が土の堨合 (CASE1)

a) 南果風 $(\mathrm{GL}+15.8 \mathrm{~m})$ の場合

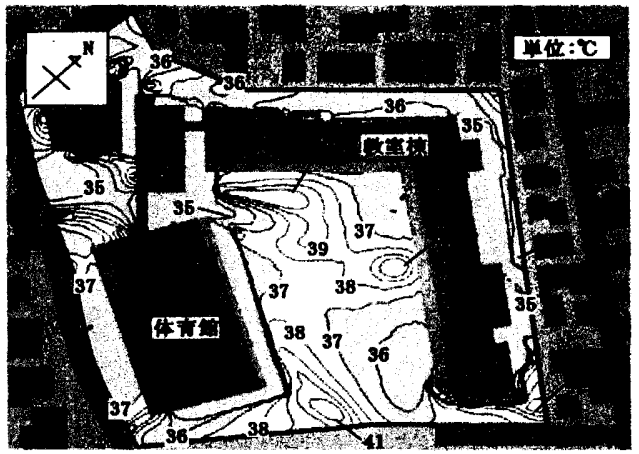

校庭が土の場合 (CASE3)

b）南西風 $(G L+15.8 m)$ の塄合

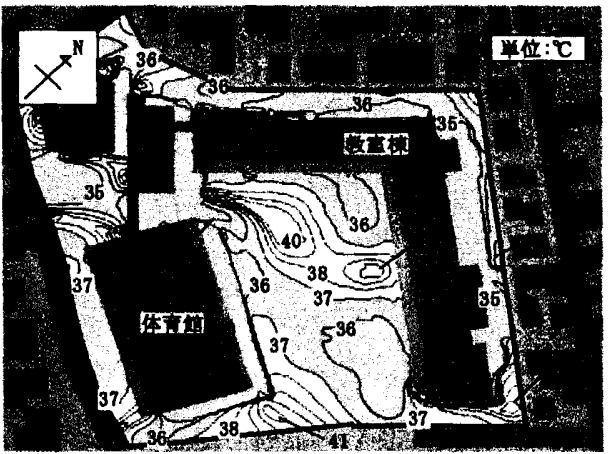

校庭が芝生の埸合 (CASE4)

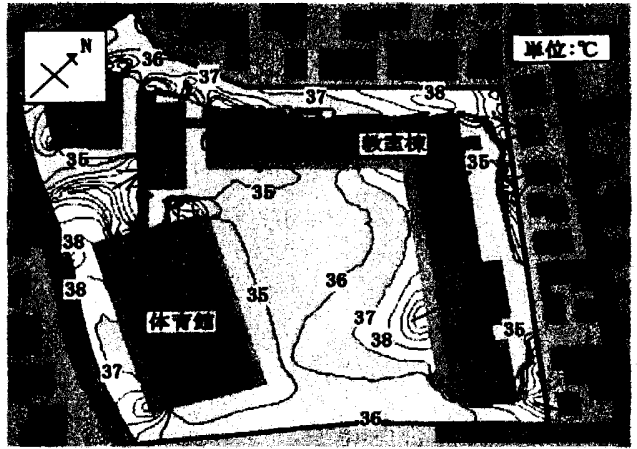

校庭が土の場合 (CASE5)

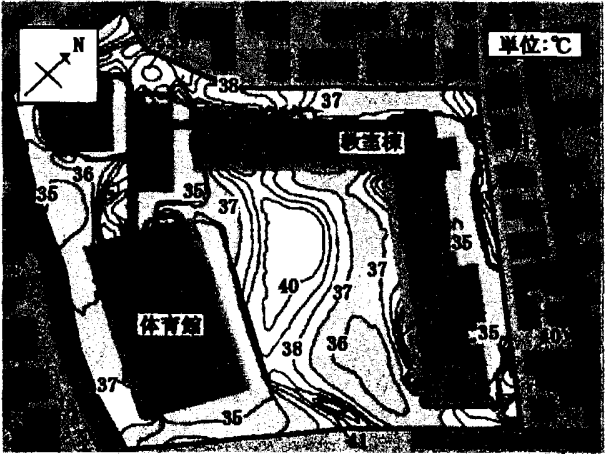

校庭が芝生の場合 (CASE2)

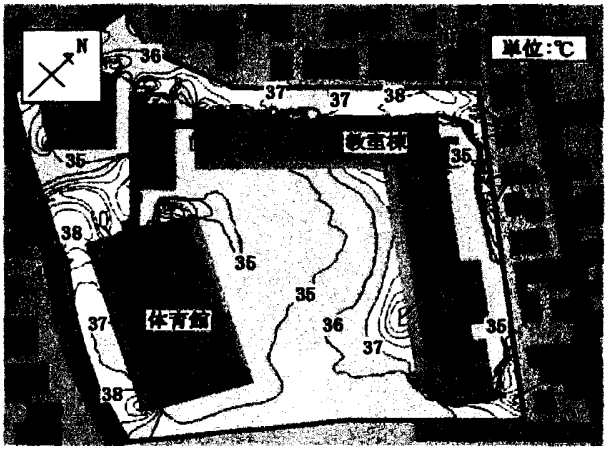

校庭が芝生の場合 (CASE6)

c）南風 $(\mathrm{GL}+15.8 \mathrm{~m})$ の場合

图10 校庭 $(\mathrm{GL}+0.6 \mathrm{~m})$ の SET *の比較 
西，南の 3 種類にした場合の $\mathrm{GL}+0.6 \mathrm{~m}$ の平面における各 $\mathrm{SET}^{*}$ を図 10 に示す。なお，SET*の算出にはGagge ら ${ }^{12)}$ が提案したTwo Node Modelによる計算方法を用いる。南東風の場合(図 10 の) は, 校庭の教室棟側における $37^{\circ} \mathrm{C}$ 以下の領域(色塗り部分) が，芝生の 場合が士の場合より広くなる。南西風の場合(図 10 の b) も, $37^{\circ} \mathrm{C}$ 以下の領域が芝生の場合が土の場合より広くなり,校庭の体育館側 から教室棟側にかけて $37^{\circ} \mathrm{C}$ 以下の領域が芝生の場合にできる。南風 の場合（図 10 の c) は, $37^{\circ} \mathrm{C}$ 以下の領域が士の場合も芝生の場合 もほぼ同一であるものの， $35^{\circ} \mathrm{C}$ 以下の領域が芝生の場合が土の場 合より広くなる。従って, 南寄りの風が吹く場合, 現地のような校 舎の配置であれば，芝生の校庭のほうが土の校庭より SET*が局所 的に $1^{\circ} \mathrm{C}$ 程度低くなる傾向がある。これらの結果は, 芝生の校庭が 土の校庭より校庭の温熱環境を改善することを示している。

（3）教室棟内部における風速と温度の分布

図 10 で比較した南寄りの3風向において教室棟内部での通風が あると予想していたが，現地のような校舎配置は，例えば図 9 の aに示すように，教室棟の外壁に付着する気流や外壁付近で旋回 する気流が発生し, 室内一の気流の流入が少ないことが解析結果 から判明したため，教室棟の外壁に垂直な方向から校庭の空気を 教室棟内部へ強制的に流入させた場合を想定して2次元断面で教室 棟内部の室温分布の比較を行う。図 2 の教室棟 $\mathrm{x}$ - $\mathrm{x}^{\prime}$ 断面における風 速と空気温度の分布を図 11 に示寸。なお, 流入風条件には, 風速 は $\mathrm{GL}+15.8 \mathrm{~m}$ の高さで $3 \mathrm{~m} / \mathrm{s}$ となる $1 / 4$ 乗則の風速プロファイルで, 温度は図 9 の気温分布で図 2 の $x^{-} x^{\prime}$ 断面における温度分布で与え る。その他の計算条件は表 5 に示寸とおりで, 教室には机は無く， 教室と廊下の間仕切り壁にある空や扉は全開の状態を設定する。

風速分布は図 9 の a で示すように芝生の校庭上十の校庭の風速 分布の差違が小さいので，校庭が芝生の場合の風速分布のみを図 11 の a に示す。教室棟内部へ流入した気流は, 教室で下半分が旋 回流となって廊下一流入し屋外一流出寸る流れになる。また, 各階 の教室での風速は $0.5 \mathrm{~m} / \mathrm{s}$ 程度である。

1 階の室温については，士の校庭の場合（図１１のb) では，地 表面付近の $34^{\circ} \mathrm{C}$ から $35^{\circ} \mathrm{C}$ 外気が教室内人流入して室温が約 $34^{\circ} \mathrm{C}$ になる。一方，芝生の校庭の場合(図 11 の c) では, $33^{\circ} \mathrm{C}$ から 34

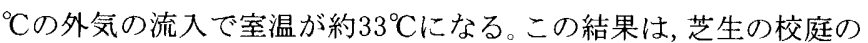
空気が校舎内に流入することによって, 室温が $1{ }^{\circ} \mathrm{C}$ 程度は低下する 可能性があることを示唆している。なお，教室棟内部の室温が流入 空気より低くなるのは，教室棟の躯体温度を $26^{\circ} \mathrm{C}$ に設定(表 5 ) し たためである

校庭側の犬走りの日射受熱で空下部の屋外側の空気が暖められ ていることに着目して, 犬走りをコンクリートから保水材料(蒸発 効率が 0.3 の材料) に置き換える (図 11 の d) と, 1 階の教室の室 温がさらに低くなる傾向を示す。なお，図 12 に示す現地調査の昼 間で, 図 11 と同じ X-X’ 断面での 1 階教室の室温に対する校庭中 央 $(\mathrm{GL}+0.6 \mathrm{~m})$ や犬走り $(\mathrm{GL}+0.6 \mathrm{~m})$ での気温の差においても, 犬走り で気温が上昇する傾向がある。

2 階以上の室温については, 2 階では, 土の校庭の場合 (図 11 の b ) では $33^{\circ} \mathrm{C}$ か $34^{\circ} \mathrm{C}$ 外気が空内一流入して $31^{\circ} \mathrm{C} か ら 33^{\circ} \mathrm{C}$ 程度 の室温になるが, 芝生の校庭の場合(図 11 の ) では $32^{\circ} \mathrm{C}$ 放 33 ${ }^{\circ} \mathrm{C}$ 外気が室内人流入して $31^{\circ} \mathrm{C} か ら 32^{\circ} \mathrm{C}$ 程度の室温になる。3階で

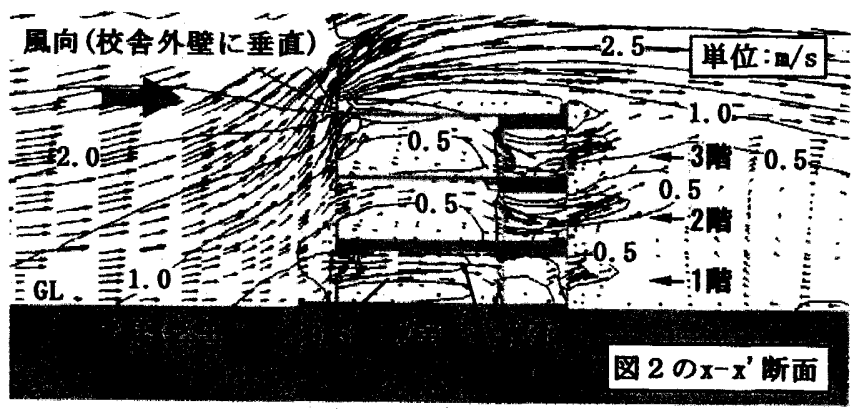

a）囷速 (CASE8，校庭：芝生）

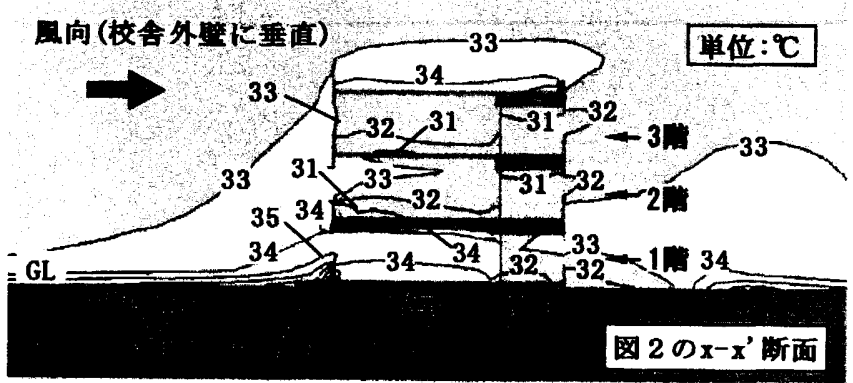

b）空気温度 (CASE7，校庭：土，犬走り：コンクリート）

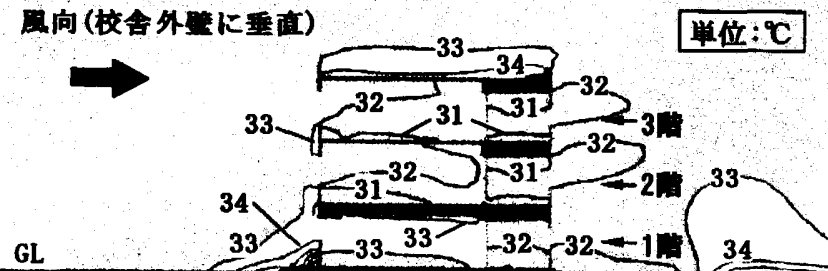

图 2 のx-x’所面

c）空氛温度 （CASE8，校庭：芝生，犬走り：コンクリート）

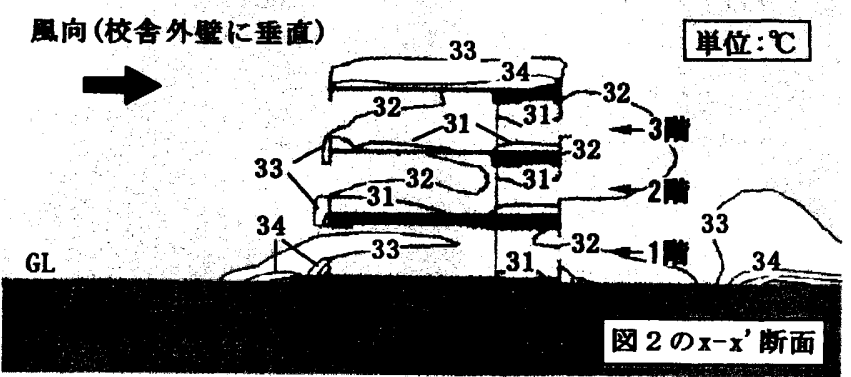

d）。空氛温度 (CASE9，校庭：芝生，犬走り：保水材料)

図 11 教室棟断面の風速と空気温度の分布
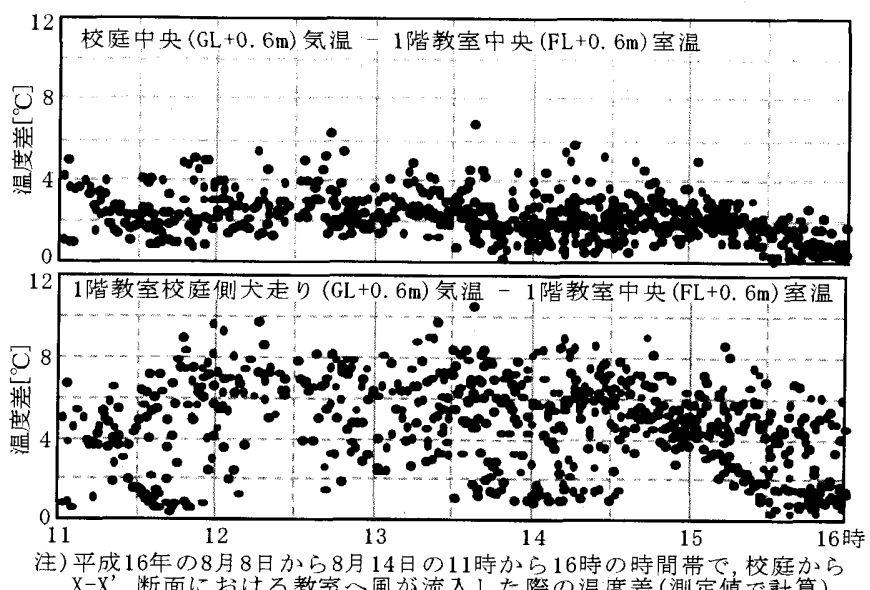

図 12 校庭中央や犬走りでの気温と 1 階教室の室温との差 
は，芝生の校庭による影響は2 階よりも小さくなる。犬走りを保水 材料に置き換えた場合における2階や 3 階の室温への影響について はほとんど無い。なお, 現地のA小学校の屋上は表 5 に示すとおり 断熱材がないので, 屋上緑化を行うなどの屋上の断熱対策が3階の 室内温熱環境の改善には効果があると思われる。

\section{5. 結論}

本研究では, 土の校庭や芝生の校庭の放射特性や蒸発効率等の物 理量の測定値を CFDによる数值シミュレーションの与条件に用い て, 校舎や近隣建物の形状や配置を再現した計算モデルで計算し， 土の校庭や芝生の校庭による校内の夏季における熱環境を比較し た。風向・風速や温湿度が定常状態を想定して計算した結果，校庭 の芝生化による校庭や校舎内の暑熱環境の緩和効果について得ら れた知見は以下のとおりである。

(1) 校庭の南東側以外は校舎で用まれた計算モデルでは, GL+15.8m の高さで南東風の場合, GL+0.6mの高さにおいて, 気流が停滞す る領域 (風速が $0.5 \mathrm{~m} / \mathrm{s}$ 以下) が校庭内で発生し，その領域で芝

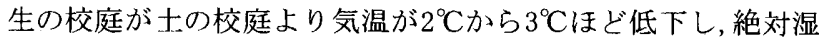

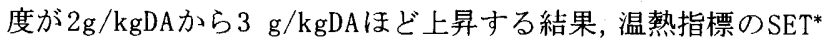
は芝生の校庭が土の校庭より局所的に $1^{\circ} \mathrm{C}$ 程度低くなる。また， 風向が南西や南の場合でもSET*については同様な傾向を示す。

(2) 校舎内一校庭の空気が流入し室内風速が $0.5 \mathrm{~m} / \mathrm{s}$ 程度になる状 況における教室の室温は, 校庭が芝生の場合が校庭が十の場合 より 1 階では $1{ }^{\circ} \mathrm{C}$ 程度低下するが，上階へいくほど低下傾向は 弱まる。犬走りをコンクリートから蒸発効率 0.3 の材料に変え ると 1 階の室温はさらに低くなるが，上階一の影響は無い。

\section{謝辞}

本研究を進めるにあたり，東京都目黒区教育委員会や現地調査 をさせて頂きました学校の関係者の方々には多大なるご協力を頂 きました。また, 大成建設侏技術センタ一の屋袮下亮氏には現地調 查に関してご指導を頂きました。ここに記して深謝いたします。

\section{注}

注 1 ） 5 月の測定は，学校や地域交流による制約があったので, 測 定期間が短くなっている。

注 2 ）試験体の製作で配慮した内容は次のとおりである。

1) 土ユニット：6月に実施した芝張り工事で土の校庭を掘削 した際に取り出した土壤の層状固形物をなるべく破壊しない ようにして屋外実験場所に持ち帰り, 表層の地表面を上面に して, 各層の厚さと材料構成について, 現地での状況を出来 る限り再現して製作している。

2) 芝生ユニット: 芝張り工事で使用した同じ芝生(十壌は黒 十）と砂を使って，黒士と砂の層の厚さの合計を士ユニット の石灰質十培と荒木田土の層の厚さの合計と同じにして, 校 庭の芝張り時期と同じ時期に製作している。屋外実験が終了 するまで現地での散水時刻と散水量にあわせて芝生を育成し ている

注 3 ) 図 8 で示寸芝生ユニットの蒸発効率が 1 を超えているのは , 8 月 12 日の最大值 1.08 の $(8$ 月 10 日の最大值は0.99)で ある。式(2)で計算した蒸発効率が1を超えた理由は, 芝生の 表面温度の測定值 (任意の5筒所の平均值)が芝生ユニットの
表面温度を正確に代表していないことが考えられる。しし ながら，既往の調査として，例えば二坂ら ${ }^{14)}$ の調査結果で は, 早朝に降雨があった日の芝生の蒸発効率が 0.7 から 0.8 程度であることから, 図 8 で示す毎朝散水した芝生ユニット の蒸発効率(8月 8 日から 8 月 14 日までの平均值 0.70) はほ ぼ妥当な值を示していると考えられる。なお, 蒸発効率 1.08 の值を除いた 8 月 12 日以降 3 日間の 10 時から 15 時までの 蒸発効率の平均值が 0.72 で変化が小さいことから, CFD解析 における計算結果においても影響は小さいと考えられる。

注 4 ) 図 8 で示す士ユニットの蒸発効率が晴天初日 (8 月 8 日) で1 を超えている部分 (1.1 から 1.2 程度) があるが, 原因として は，散水翌日で土ユニットの表面が十分に濡れている状態 に対して, 表面温度の正確な測定ができていないことが考え

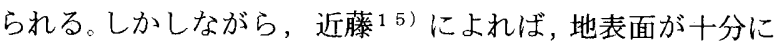
濡れている状態での蒸発効率は限りなく1に近い値を示すこ とから，図8の晴天初日の十ユニットの蒸発効率は多少高 めではあるが, 表面が十分に濡れている状態を示しており， 目視でも確認している。なお, 晴天初日の蒸発効率はCFD解 析の計算条件ではないので，計算結果に影響はない。

\section{参考文献}

1）梅田和彦，深尾仁，田村明弘：熱環境の評価における樹木の夏季蒸散量に関 する基礎的検討，日本建筑学会環境系論文集 第601 号,pp. 15-20, 2006.3

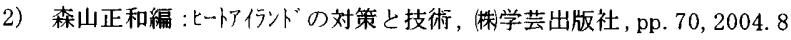

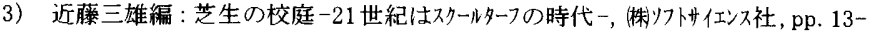
$16,2003.5$

4）浅野義人：校庭の芝生化一技術面に扰ける課題と展望, 芝草研究 第32巻 第 2 号, pp. 117-121, 2004.3

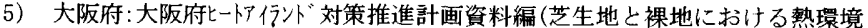
比較結果), pp. 13-24, 2004.6

6）神田学，森脇亮，高柳百合子，横山仁，浜田崇：明治神宫の森の気候緩和機 能・大気浄化機能の評価 (1) 1996 年夏期集中観測, 日本気象学会, 天気 44. 10 , pp. $31-40,1997.10$

7) 尹龍漢, 丸田頼一, 本條毅, 柳井重人 : 都市に扔ける公園内外の気温分布特 性について,ランド欢つ’研究 61 (5),pp. 769-772, 1998

8）森山正和, 河野仁, 吉田篤正, 宮崎ひろ志, 竹林英樹 : 都市に扔ける樹林の クートズッ外効果に関する実測デー多解析，日本建築学会計画系論文集 第 541 号 ,pp. 49-56, 2001.3

9）山田宏之，佐藤忠継，澤田正樹，岩崎哲也，角田里美，楸父志乃夫：環境共 生住宅団地の緑化による微気象緩和効果について,ランドスケーブ研究 62 (5) ,pp. 635-638, 1999

10）佐藤愛, 吉田治典, 伊藤麻美子, 村上大輔 : 集合住宅の住棟間における榯木 の気候緩和効果に関寸る研究, 日本建築学会環境系論文集 第587号, pp. 79$85,2005.1$

11）梅田和彦, 深尾仁, 大黒雅之：校庭の芝生化による夏季熱環境の緩和効果に 関寸る研究一数值シシュレーションによる土の校庭と芝生の校庭の比較一, 日本建築 学会大会学術講演梗概集 環境工学 I, pp. 673-674, 2005.9

12) A. P. Gagge, A. P. Fobelets, L. G. Berglund:A Standard Predictive Index of Human Response to the Thermal Environment, ASHRAE Transactions, Vol. 92, Part 2, pp. 709-731, 1986

13）村上周三著：CFDに上る建築・都市の環境設計工学, (財) 東京大学出版会 pp. $299,2000.9$

14）三坂育正, 石井康一郎, 横山仁, 山口隆子, 成田健一: 軽量·薄層型屋上緑 化技術のヒ一トア仿ンド 緩和効果の定量評価に関寸る研究, 日本建築学会技術報 告集第 21 号, pp. 195-198, 2005. 6

15）近藤純正編著：水環境の気象学，㥪朝倉書店, pp. 129, 1994.4

16）大黒雅之, 森川泰成, 梅田和彦, 屋弥下亮, 深尾仁: 建筑·設備加ら見た七一卜 ア估々ド対策技術とその評価，大成建設技術セ多一報第 37 号, 2004

17）義江龍一郎: STREAMによる計算結果と実駼結果の比較一角柱周りの流れ場に ついて - 第十回エーザー事例発表会講演集，2000

18）梅市野昆, 白井一義, 大塚修弘, 岩村和夫: 薄い盛土層を持った屋上芝生植 栽の木造建物における室内熱環境調整効果，日本建築学会計画系論文集第 527 号, pp. 15-20, 2000. 1

（2006年 3 月 10 日原稿受理，2006年 7 月 14 日採用決定） 